\title{
Utilization of Used Wood as Material Structure and Construction of Sitinggil House Buildings
}

\author{
Theresia Pynkyawati ${ }^{1}$, Ekat Lesmana ${ }^{1}$, Deden Sukendar ${ }^{1}$ \\ ${ }^{1}$ Department of Architecture, Faculty of Architecture and Design, Itenas, Bandung \\ thres@itenas.ac.id
}

\begin{abstract}
Material plays an essential role in constructing a house because it becomes a constituent element for the establishment of a building. Sitinggil Dago Residence, located on Jalan Dago Giri, Bandung, West Java, is a house with two functions. This house is interesting because overall, it uses wood as a structural and construction material by accentuating the structure of the building, which is left without finishing. The method used in this research is a descriptive analytical-qualitative method by observing the structure and construction of used wood on roofs, columns, and beams and the foundation as a base which is then compared with the theory and standardization of the use of wood in buildings. This study shows that used wood can still be reused for structures and construction on roofs, columns, and beams in residential buildings.
\end{abstract}

(C) 2021 IJBESR. All rights reserved.

Keywords: Sitinggil House, Structure and Construction, Used Wood Material

\section{Introduction}

The material is vital to building the house for being one of the building blocks for establishing a building. An increase in the percentage of development every year in west java regional Lembang exactly, causing many uses the materials of felled trees and processed into blocks of wood. The need for wood as a building material and industrial at present tends to be increased, while supplies of wood from the forest are not enough because of the consequent excessive exploitation of the logging to the needs of the building and industry [1].

The increasing demand for wood as structural raw materials that are not accompanied by an increase in supplies of wood made, we need to use wood for purposes of the structure and construction for sustainable development. Builders of a house indirectly have an impact on the environment. This needs to apply sustainable development (sustainable development) in their activities to utilize the whole resources to improve the quality of life. Welfare between humans and nature can be a long-term solution to save the earth from damage.

The used wood in the construction was one effort to natural conservation like home in the Sitinggil Dago on Jalan Dago Giri no. 90 Bandung West Java, Where the use of material on the building of these make use of material used wood as the structure and the construction is. The house on stilts structure had a system raised on a platform as head of roof structures, columns and beams as a body, and foundation as afoot.

Facades building interesting because there is reflect structure left without finishing. Maintenance to keep the power of enduring, 
the used wood structure was given anti termites and of building support by the foundation for the sake of avoiding the touch directly wood with earth to doesn't become clammy and worn out.

Strategic location noted for its hills that serve as the recreational tourist area local and out of town, to the opportunities in the land an owner housing construction with the structure and function of wood used for living space and a business that is in the form of a cafe to accommodate tourists that visit in this region.

\section{Material and Methods}

\subsection{Structural and Construction Systems}

The structure is the pole building, a significant power of buildings. A building consisted of element structure and elements nonstructural. Element's structure support nonstructural so to the building stout, and the building will be elements of the structure and nonstructural cohere to form the housing complexes aesthetically. All these elements are defined as construction [2].

\subsection{Roof Construction}

The roof is part of a building that serves as a cover for a whole room on the bottom of the influence of heat, rain, wind dust, or protection needs. The roof is part of a structure at the top of a structure [3].

\subsubsection{Roof Requirements}

a. Construction a roof to hold its weight and resist pressure and wind.

b. Election the form of a roof will be used adapted to, beauty, and comfortable lives for its inhabitants.

c. Need to be given a layer of a preservative (a lining tir).

d. The cover of a roof is resistant to the influence of climate change. e. The slope or angle to the top must be adjusted to a kind by the material cover.

\subsubsection{Roof Forms}

The roof of a house not just a means of shade. The form of the roof affected air circulation and comfort all who are below. The following are from a top that can be applied to buildings in Table 1.

Table 1. Roof Forms

\begin{tabular}{|c|c|c|}
\hline No & Type of Roof & Description \\
\hline 1 & Shed Roof & $\begin{array}{l}\text { - Often called also by } \\
\text { name a roof sengkuap } \\
\text { or roof outboard. } \\
\text { - Consisting of a sloping } \\
\text { roof area of the } \\
\text { overlying an edge } \\
\text { against or attached to a } \\
\text { wall (soaring wall). } \\
\text { - In the form of the roof } \\
\text { leaning against using } \\
\text { half truss construction } \\
\text { to support common } \\
\text { rafters. }\end{array}$ \\
\hline 2 & Gable Roof & $\begin{array}{l}\text { - Consisting of two } \\
\text { spheres sloping roof } \\
\text { that edges it met in a } \\
\text { straight line, called the } \\
\text { ridge. } \\
\text { - The lower edge of a } \\
\text { roof, where water is } \\
\text { leaving a roof called the } \\
\text { overstek. } \\
\text { - On the edges of that } \\
\text { overstek can be } \\
\text { installed gutters. } \\
\text { - At both ends of the end } \\
\text { of the wall of a building } \\
\text { have been built } \\
\text { mountains as substitute } \\
\text { trusses. }\end{array}$ \\
\hline
\end{tabular}

Source: (Supribadi, 1993)

\subsubsection{Structural Timber Trusses}

In construction, timber trusses consist of stems that are continuously always triangular form. The applications are placed at a certain 
distance according to the place that has been planned, as in Figure 1 and Table 2.

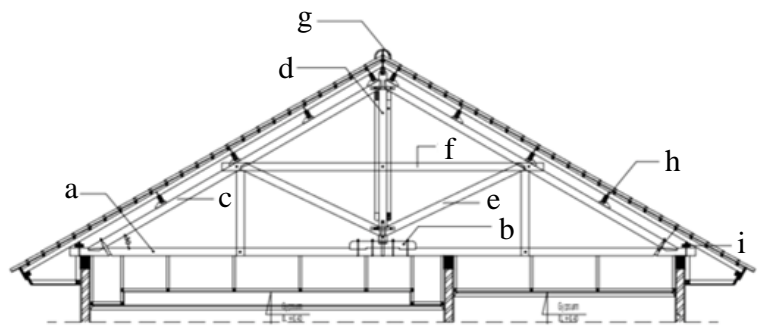

Source: (Supribadi, 1993)

Figure 1. Structural Timber Trusses

Table 2. Description of Structural Timber Trusses

\begin{tabular}{|c|l|c|c|c|}
\hline \multirow{2}{*}{ No } & \multirow{2}{*}{ Beam Name } & \multirow{2}{*}{ No } & \multicolumn{2}{|c|}{$\begin{array}{r}\text { The theory stretch (L) in } \\
\text { meter }\end{array}$} \\
\cline { 4 - 5 } & & & $6-7$ & $7-8$ \\
\hline 1 & Tie Beam & a & $7 / 14-8 / 15$ & $7 / 15-8 / 16$ \\
\hline 2 & Key beam & b & $7 / 14-8 / 15$ & $7 / 15-8 / 16$ \\
\hline 3 & Principal Rafters & c & $7 / 12-8 / 14$ & $7 / 14-8 / 15$ \\
\hline 4 & King post & d & $7 / 12-8 / 14$ & $7 / 14-8 / 15$ \\
\hline 5 & Strut & e & $7 / 10-8 / 12$ & $7 / 12-8 / 14$ \\
\hline 6 & Collar Tie & f & $5 / 12$ & $5 / 12$ \\
\hline 7 & Ridge Board & g & $7 / 14-8 / 15$ & $7 / 15-8 / 16$ \\
\hline 8 & Common Rafters & h & $7 / 14-8 / 15$ & $7 / 15-8 / 16$ \\
\hline 9 & Wall plate & i & $7 / 12-8 / 14$ & $7 / 15-8 / 16$ \\
\hline
\end{tabular}

\begin{tabular}{|c|l|c|c|c|}
\hline \multirow{2}{*}{ No } & \multirow{2}{*}{ Beam Name } & \multirow{2}{*}{ No } & \multicolumn{2}{|c|}{$\begin{array}{c}\text { The theory stretch (L) in } \\
\text { meter }\end{array}$} \\
\cline { 4 - 5 } & & & $3-4$ & $4-6$ \\
\hline 1 & Tie Beam & a & $7 / 10-8 / 12$ & $7 / 12-8 / 14$ \\
\hline 2 & Key beam & b & $*)$ & $7 / 12-8 / 14$ \\
\hline 3 & Principal Rafters & c & $6 / 8-8 / 12$ & $7 / 10-8 / 12$ \\
\hline 4 & King post & d & $7 / 8-8 / 10$ & $7 / 10-8 / 12$ \\
\hline 5 & Strut & e & $*)$ & $6 / 8-8 / 10$ \\
\hline 6 & Collar Tie & f & $*)$ & $5 / 10$ \\
\hline 7 & Ridge Board & g & $7 / 10-8 / 12$ & $7 / 12-8 / 14$ \\
\hline 8 & Common Rafters & h & $7 / 10-8 / 12$ & $7 / 12-8 / 14$ \\
\hline 9 & Wall plate & i & $7 / 8-8 / 10$ & $7 / 10-8 / 12$ \\
\hline
\end{tabular}

Source: (Priambodo, 2008)

\subsection{Column and Beam Structure}

\subsubsection{Column}

The function of a column as the successor of the burden of vertical from all buildings to the structure down the foundation. The column of the main structure to continue heavy load the building and other heavy like human and things, And the wind gusts [4]. Columns define the wall height and stand perpendicular to the bearing and the role of the wall [5].

Table 3. Wooden Column Size

\begin{tabular}{|c|l|c|c|c|}
\hline No & Pillar/Column Name & \multicolumn{3}{|c|}{ Column Dimensions (cm) } \\
\hline 1 & Square Column & $10 / 10$ & $12 / 12$ & - \\
\hline 2 & Rectangular Column & $10 / 12$ & $12 / 14$ & $12 / 16$ \\
\hline
\end{tabular}

Source: (Frick Heinz, 1982)

\subsubsection{Beam}

System beams are divided into two types of main beams and joists on the construction. The main beam has a force of the column above, beam ring, slab, and wall as for joist receive pressure and load of a slab, then channel force and this burden to the main beam structural [6].

Table 4. Wooden Beam Dimensions

\begin{tabular}{|c|l|c|c|c|c|}
\hline No & \multicolumn{1}{|c|}{ Beam Name } & \multicolumn{4}{|c|}{ Beam Dimensions $(\mathrm{cm})$} \\
\hline 1 & Beams for Bearings & $6 / 8$ & $8 / 8$ & $8 / 10$ & $10 / 10$ \\
\hline 2 & $\begin{array}{l}\text { Beams for Wall } \\
\text { Role }\end{array}$ & $8 / 12$ & $\begin{array}{c}10 / 1 \\
2\end{array}$ & $\begin{array}{c}10 / 1 \\
4\end{array}$ & $12 / 14$ \\
\hline 3 & Beams for Pillar & $8 / 8$ & $\begin{array}{c}10 / 1 \\
0\end{array}$ & $\begin{array}{c}12 / 1 \\
2\end{array}$ & - \\
\hline 4 & $\begin{array}{l}\text { Beams for Support } \\
\text { truss }\end{array}$ & $8 / 8$ & $8 / 10$ & $\begin{array}{c}10 / 1 \\
0\end{array}$ & $10 / 12$ \\
\hline 5 & Beams for Gutters & $6 / 8$ & $8 / 8$ & $8 / 10$ & $10 / 10$ \\
\hline
\end{tabular}

Source: (Frick Heinz, 1982)

\subsection{Foundation}

The foundation is umpak, made of stone, wood, and concrete formed, round, dimples, or cube. The material is made to prop up poles supporting it [7]. The foundation umpak is commonly used by cafes and restaurants as facilities entitled lesehan. There is ornamental to make the restaurant as houses the stilts, gazebo sited or Saung the form of the foundation can be seen from Figure 2. 
Table 5. Characteristics of Wood

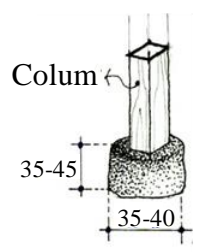

Umpak Stone Circle (intact)

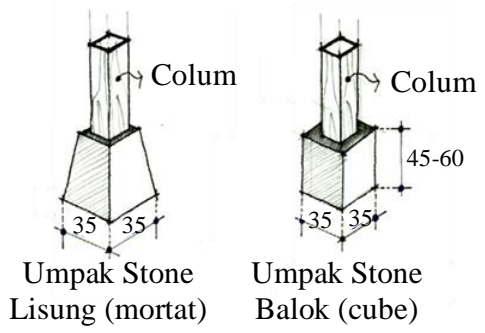

Source: (Nuryanto, 2006)

Figure 2. The Foundation Umpak

\subsection{Used Wood Material}

\subsubsection{Types of Wood}

At least the use of many kinds of wood by consumers seen of a class and the durability power kinds of wood concerned [8]. The following the categorization of wood based on the level of their endurance, As the following:

a. Rank 1 and rank 2: For heavy constructions, unprotected and exposed moist soil (Rank I: Jati, Merbau, Bengkirai, Belian woods), (rank II: Rasamala, Merawan woods).

b. Rank 3: For construction heavily to protect (Puspa, Kamper, Kruing woods)

c. Rank 4: For lightweight construction to protect (Meranti, Suren, Jeungjing).

d. Rank 5: For temporary occupation.

\subsubsection{Utilization Used Wood Material}

As important in building material, in the form of truss wood used for roofing, order to cover the roof, the ceiling of the order, the jamb, doors, and windows [9]. Wood sold on the market there are two characteristics namely new wood and used wooden by having each advantage and disadvantages [10].

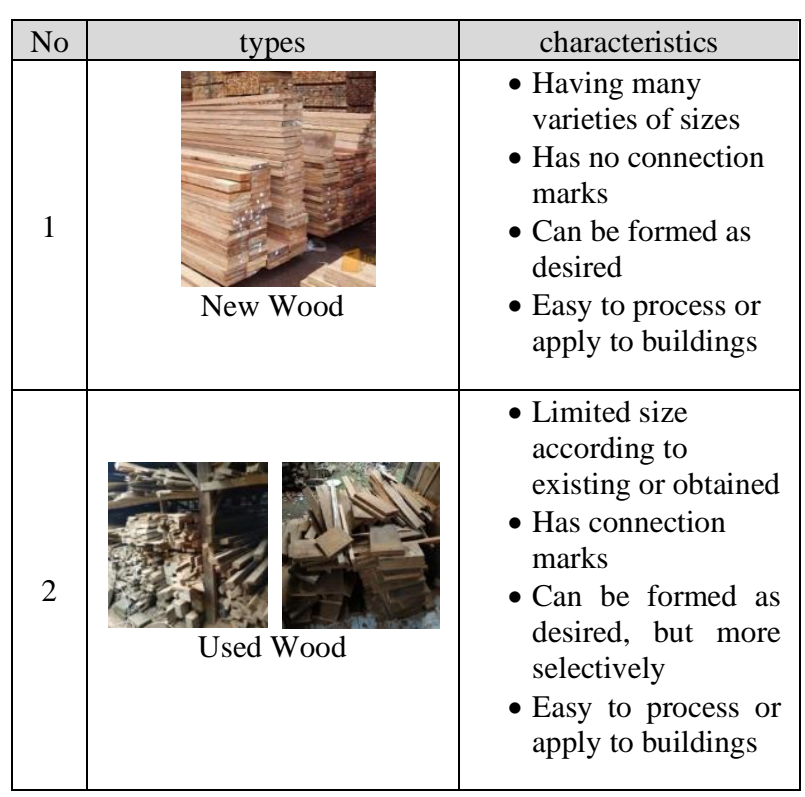

Source: (Kalingga Gallery, 2019)

\subsubsection{Obtaining of Used Wood}

a. Supply from scavengers

An adequate supply of goods former resulting scavengers is relatively not constant can be obtained every day. An adequate supply of used goods produced by scavengers is relatively unchanged, which can be obtained every day.

b. Participating in a building demolition auction

The auction must meet administrative requirements and follow the auction process from the initial stage until the winner is determined.

c. Buy building demolition

Usually, you get a personal offer from the building that will be demolished if you are interested in destroying the building. You will continue to look in detail and quantify the various types of building components that can still be used [9].

\subsubsection{Used Wood Processing}


The processing of used wood is carried out in several stages to obtain the quality and shape of usable used wood as needed [11], which can be seen from Table 6 .

Tabel 6. Used Wood Processing

\begin{tabular}{|c|c|c|}
\hline No & Process & Explanation \\
\hline 1 & Cutting & $\begin{array}{l}\text { The used wood in the form of } \\
\text { blocks is split and cut so that the } \\
\text { shape and size are the way you } \\
\text { want it. } \\
\text { - This initial process is a basic } \\
\text { process which is still a rough } \\
\text { process. }\end{array}$ \\
\hline 2 & Drying & $\begin{array}{l}\text { - The wood is dried first using a } \\
\text { special machine and the room so } \\
\text { that it can reach an air content of } \\
\text { around } 8-12 \% \text {. } \\
\text { - Measure the moisture content of } \\
\text { wood using a special moisture } \\
\text { gauge for wood. }\end{array}$ \\
\hline 3 & $\begin{array}{l}\text { Assembly } \\
\text { Line }\end{array}$ & $\begin{array}{l}\text { Visually sorted wood, } \\
\text { mechanically sorted wood, } \\
\text { structural glulam wood, wooden } \\
\text { stakes, wooden posts, pre- } \\
\text { fabricated wood I-joist, structural } \\
\text { composite wood, structural wood } \\
\text { panels. }\end{array}$ \\
\hline 4 & Preservation & $\begin{array}{l}\text { This durable wood specification } \\
\text { for housing and buildings } \\
\text { includes terms and conditions for } \\
\text { wood and wood preservative, as } \\
\text { well as requirements for durable } \\
\text { wood. } \\
\text { - Gives a preservative layer to the } \\
\text { wood to increase the durability of } \\
\text { the wood to make it stronger. }\end{array}$ \\
\hline 5 & Finishing & $\begin{array}{l}\text { - Painting affects the aesthetic } \\
\text { value of the wood. } \\
\text { - Change both the look and color } \\
\text { of the wood and this process is } \\
\text { usually the most repeated } \\
\text { processes }\end{array}$ \\
\hline
\end{tabular}

Source: SNI 03-6851-2002 A method of testing structural wood panelling pliant

\subsection{Methodology}

Methods used in it will be analytical method research descriptive in qualitative and quantitative by observed regulation, theory, and Standardization that deals with the structure and construction with the structural components covering the roofs, column, beam, and foundation of the sitinggil house. The stages of this study start with the search for the structure and construction problems related to sustainable development to be at this time maintain preserve nature. This problem in terms of the use of its wood used in terms of, dimensions, connection a measure of length, and processing to function building. This has led to the underlying rationale for writers to review the housing complexity use used wood in the structure of the material and construction with doing the data collection and a recent survey of research on an object. The results of the data collected on the building that uses material used wood in the roof, column, beam, and the foundation as the pillar of a column to be turned into a subject matter that compares with the theory and standard of dimension, connection, a measure of length, according to usage and processing materials at the whole wood on the building.

\section{Results and Discussions}

\subsection{Analysis of Utilization of Used Wood Materials in Construction and Structures Systems}

The Sitinggil house is a sustainable house that utilizes used wood materials for its structural and construction systems [12]. It stands surrounded by other buildings that have been built previously, as shown in Figure 3. Apart from being a place to live in this house, the owner also uses it as a cafe to receive visitors traveling and resting in the area around Dago. This building is like a general building with a roof structure system as the head, columns, and beams as the body, and the column supports as legs, as shown in Figure 4. 


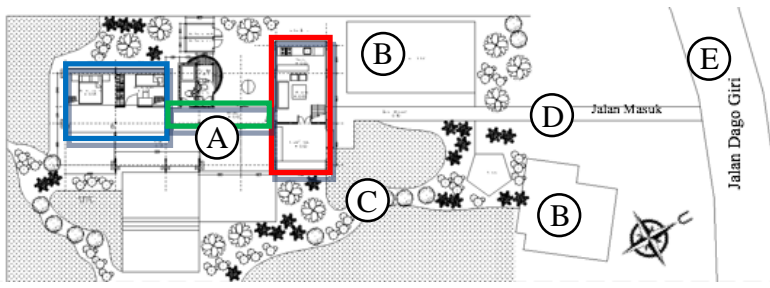

Information:

A. Dago Sitinggil House

C. Garden

\begin{tabular}{ll}
\hline & House \\
\hline & Teracce \\
\hline & Cafe
\end{tabular}

D. Entrance

E. Way Out

B. Neighbour Family House

Source: (Author, 2021)

Figure 3. Site Plan, Sitinggil House Mass Order

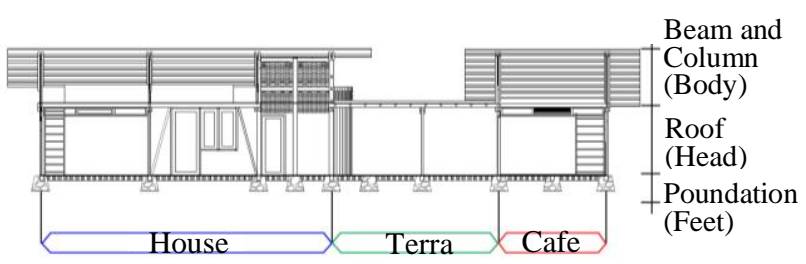

Source: (Author, 2021)

Figure 4. Section of The House Sitinggil

\subsubsection{Roof Structure}

The roof analysis was done at mass building that is divided into three the corresponding part of a mass of building covering the roofs of function in a dwelling house, terrace, and cafe with a description as follows:

a. The Roof on Homes

The roof of a residential house uses a half gable roof with a slope of $30^{\circ}$. According to theory, the span of a residential house is $5.73 \mathrm{~m}$ which includes a stretch of 4-6 m with truss an $8 / 14 \mathrm{~cm}$ easel. Because the house uses wood measuring $6 / 12 \mathrm{~cm}$ to meet these standards, used wooden blocks are arranged into $2 \times 6 / 12 \mathrm{~cm}$ using clamped flats to get a bigger and stronger dimension. This roof uses clamp beam connections, as in Figure 6.

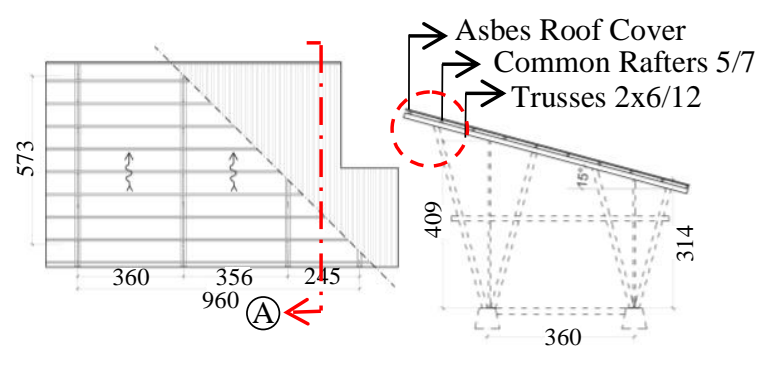

(a)Roof Layout

(b) Roof Section A-A

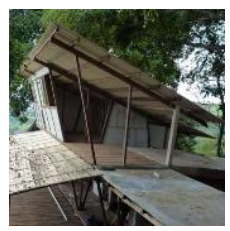

(c) Roof Images

Source: (Author, 2021)

Figure 5. Roof Construction of House Buildings (a, b, c)

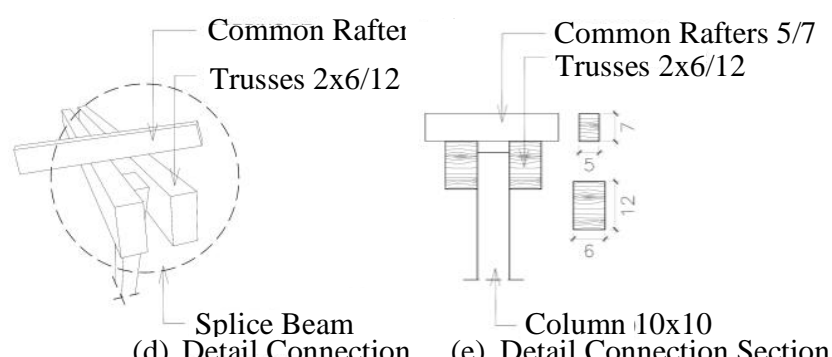

(a) Roof L

(e) Detail Connection Section

Source: (Author, 2019)

Figure 6. Roof Frame Connection Details (d, e)

b. The Roof on the terrace

The roof terrace uses a half-gable roof type. The slope of the roof on it is $10^{\circ}$. The span of the veranda roof is $1.65 \mathrm{~m}$ with used wooden trusses $2 \times 5 / 7 \mathrm{~cm}$, and it meets the standard if it is related to the theory [2] because, in a span of $3 \mathrm{~m}$ feet, the truss used are $7 / 10 \mathrm{~cm}$ on this roof using collar tie connections as in Figure 7. 


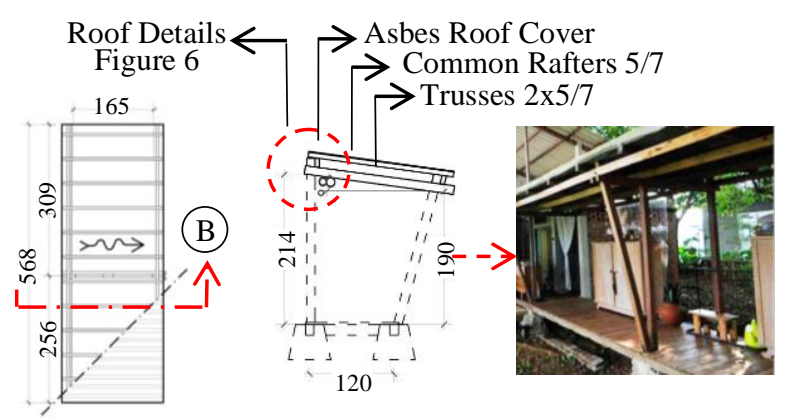

$\begin{array}{lll}\text { (a) Roof Layout (b) Roof Section B-B } & \text { (c) Roof Images }\end{array}$ Source: (Author, 2021)

Figure 7. Roof Frame of The Terrace (a, b, c)

c. The Roof on the cafe

The cafe's roof uses a half-gable roof, which has been developed again on the front, which is given cover and window openings like the building facade. The slope angle used is $30^{\circ}$. According to theory, its span at this cafe is $9.35 \mathrm{~m}$ which is included in an 8-10 $\mathrm{m}$ stretch with a truss size of $8 / 16 \mathrm{~cm}$. Because the cafe uses $6 / 12 \mathrm{~cm}$ used wood to meet the standard, used wooden blocks are arranged into 2 x 6/12 $\mathrm{cm}$ using clamped flats to get a bigger and stronger dimension on this roof using collar tie connections as shown in Figure 8.
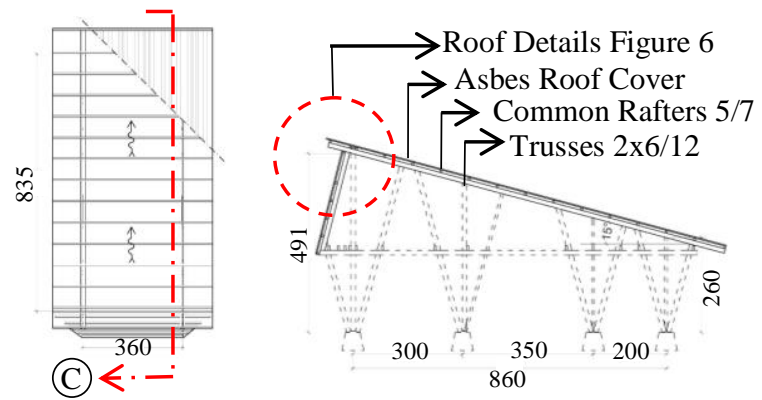

(b) Roof Section C-C

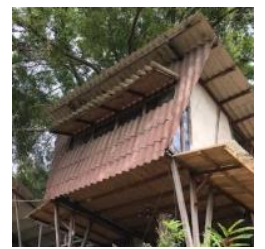

(c) Roof Images

Source: (Author, 2021)

\subsubsection{Beam and Column}

The beam and column joints used in the Sitinggil house are spliced and half-lap titled joints. Columns that are sized according to the standard are not being connected. Judging from the size of the columns and beams in this building, the sizes vary according to the availability of used wood.

a. Column in Residential and Terrace

Columns in residential buildings and terraces do not use joints because the wood used is intact, according to theory [5], which measures 10/10 as in Figure 11.

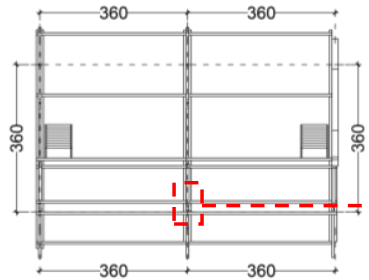

(a) House Coloumns and Beams Layout (b) House Coloumns and Beams Section
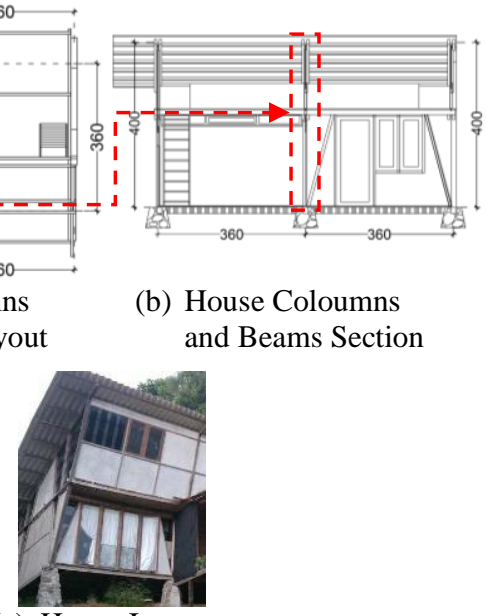

(c) House Images

Source: (Author, 2021)

Figure 9. House Columns and Beams (a, b, c)

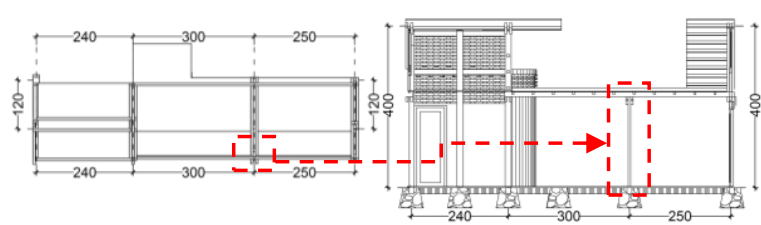

(a) Terrace Columns and Beams Layout

(b) Terrace Columns and Beams Section

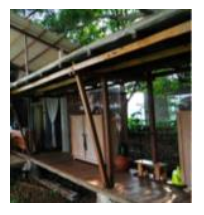

(c) Terrace Images

Source: (Author, 2021)

Figure 10. Terrace Columns and Beams (a, b, c)

Figure 8. Roof Frame of The Cafe (a, b, c) 


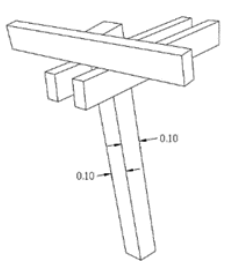

(a) Detail house and (b) Terrace Columns

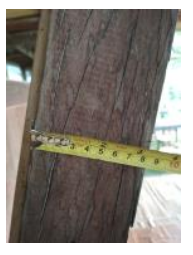

Source: (Author, 2021)

Figure 11. Detail House and Terrace Column (a, b, c)

b. Column in Café

The column in the cafe building is 4 meters long, while the supply of used wood of this size is limited so it requires a connection. The connection used is squared splice tilted and the column used is measuring 10/10 already in accordance with the theory [5] as shown in Figure 13.

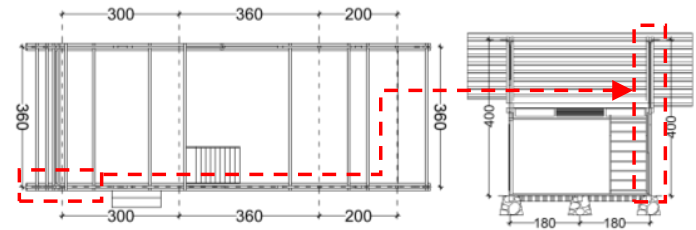

(a) Café Columns and Beams Layout

(b) Cafe Column and Beams Section

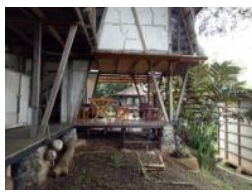

(c) Café Images

Source: (Author, 2021)

Figure 12. Café Columns and Beams (a,b, c)
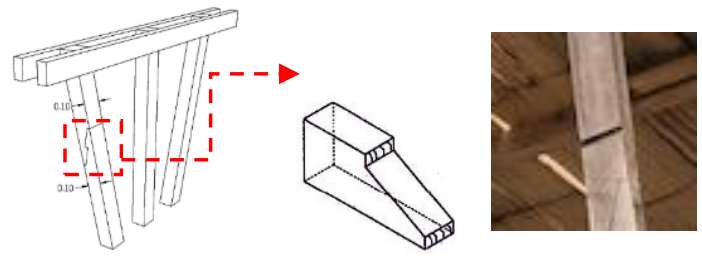

(a) Detail Café Column

(b) Detail squared splice tilted

(c) Café columns images

Source: (Author, 2021)

Figure 13. Detail Café Columns (a, b, c) c. Beam in Residential and Terrace

The length of the beam in the residence and the terrace is 3.6 meters. The beam connection with the column on residential \& terrace buildings uses splice joints. Because the size of used wooden blocks $6 / 12$ does not meet the requirements for a span of 3.6 meters according to theory 5, then a clamp joint is used with the beam dimension 2x6 / 12 as shown in Figure 14.

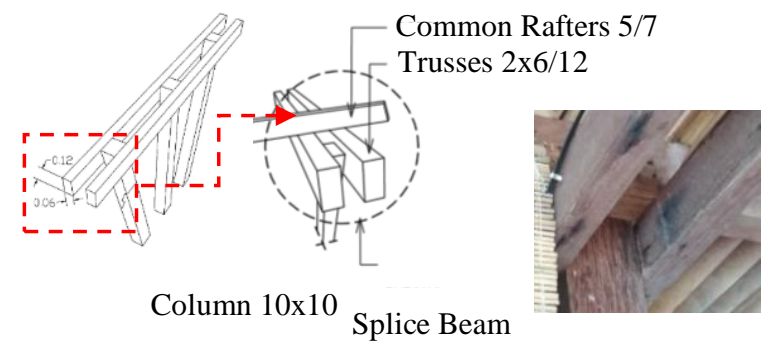

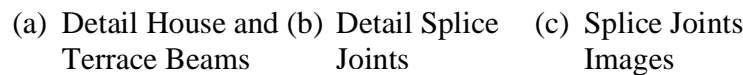

Source: (Author, 2021)

Figure 14. Detail House and Terrace Beams (a, b, c)

d. Beam in Café

The length of the beam of the café same as the terrace is 3.6 meters. The beam joints in the columns in the cafe building use Joints Images half-lap joints. The size of the 10/12 block according to theory [5] and isosceles triangle with a leo size of about $15 \mathrm{~cm}$ and

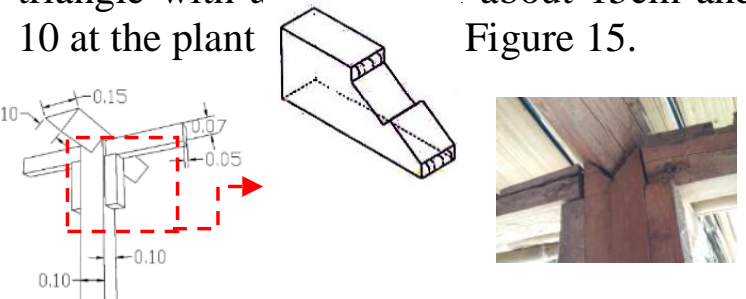

(a) Detail Café (c) Detail Tilted Half (b) Tilted Half Lap Beams Lap Joints Joints Images

Source: (Author, 2021)

Figure 15. Detail Café Beams (a, b, c)

\subsubsection{Foundation}

The foundation used in the Sitinggil house building as a whole uses the umpak foundation with the type of mortar and cube. By the theory of the umpak foundation, the foundation of the sitinggil dago house belongs 
to the type of mortar. Judging from the size of the foundation in this building the size is different.

a. Foundations in Residential and Café

The foundations used in residential houses and cafes are categorized as umpak foundations with a type of mortar according to theory [7] made of river stone with dimensions of $100 \mathrm{~cm}$, top width $30 \times 30 \mathrm{~cm}$, and bottom width $60 \times 60 \mathrm{~cm}$. The connection between the used wood column and the foundation planted is $12 \mathrm{~cm}$ deep, as deep as the used wooden beam with dimensions 8/12 as shown in Figure 16.
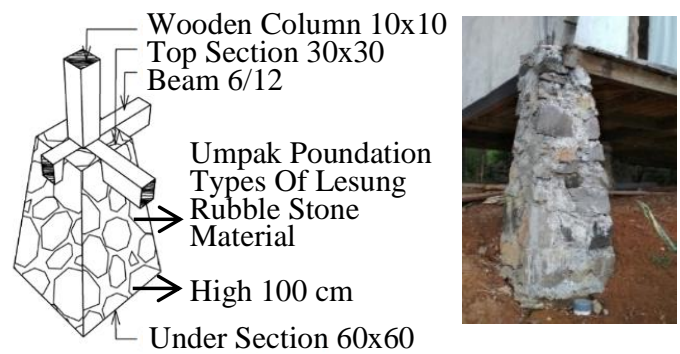
(a) Detail House and Café Foundation
(b) House and Café Foundation Images

Source: (Author, 2021)

Figure 16. Foundation House and Terrace Columns (a, b)

\section{b. Foundation in Terrace}

The foundation used on the terrace is categorized as an umpak foundation with a block (cube) type according to theory [7] made of brick with dimensions of $20 \mathrm{~cm}$ high and $30 \times 30 \mathrm{~cm}$ wide. The connection between the used wooden column and the foundation in the terrace is not planted, but the c5olumn is only placed on the foundation because it only carries a lighter load compared to houses and cafes as shown in Figure 17.

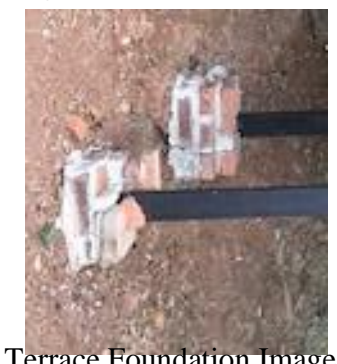

(a) Terrace Foundation Images

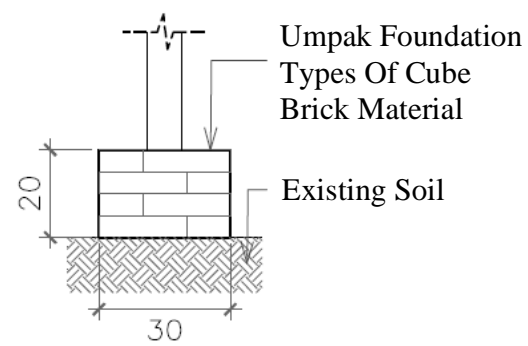

(b) Terrace Foundation Section

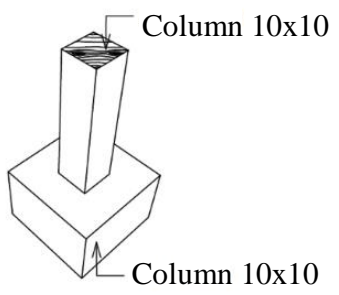

(c) Detail Terrace Foundation

Source: (Author, 2021)

Figure 17. Terrace Foundation (a, b, c)

\subsection{Used Wood Processing}

Used wood before being used for structure and construction in buildings must go through several stages so that it can be reused, if it is related to theory [11], the process of processing used wood is by the rules including in Table 7 below. 
Table 7. Used Wood Processin

\begin{tabular}{|c|c|c|c|}
\hline No. & Processing & Figure & Description \\
\hline 1 & $\begin{array}{c}\text { The Obtaining } \\
\text { Stage }\end{array}$ & & $\begin{array}{l}\text { - Used wood is obtained from participating in auctions or } \\
\text { buying directly from collectors. The wood that has been } \\
\text { obtained is sent to the workshop to be processed or } \\
\text { stored in the warehouse. Pulling out the nails that are } \\
\text { still stuck to the wood surface. }\end{array}$ \\
\hline 2 & Cutting stage & & $\begin{array}{l}\text { - The cutting stage is carried out to get the desired size so } \\
\text { that it is easier to sort. Wood is cut to various sizes } \\
\text { according to its thickness and length. When it has been } \\
\text { cut, the wood is stored according to its category and } \\
\text { type. }\end{array}$ \\
\hline 3 & Drying stage & & $\begin{array}{l}\text { - The drying process is carried out to reduce the moisture } \\
\text { content so that the wood does not develop mold or } \\
\text { mildew on the wood surface and weathering. Drying is } \\
\text { done in the traditional way, namely by exposing it to } \\
\text { the sun. }\end{array}$ \\
\hline 4 & $\begin{array}{l}\text { Assembly } \\
\text { Line Stage }\end{array}$ & & $\begin{array}{l}\text { - The assembly is done to make it easier to install in the } \\
\text { field later and if there is any cut wood it can be reused } \\
\text { or processed into furniture or accessories to beautify the } \\
\text { room. }\end{array}$ \\
\hline 5 & $\begin{array}{l}\text { Preservation } \\
\text { stage }\end{array}$ & & $\begin{array}{l}\text { - The next step is to coat the chemical liquid to provide } \\
\text { resistance to the age of the wood or to do the soaking } \\
\text { process which can be done many times according to the } \\
\text { characteristics of the wood. }\end{array}$ \\
\hline 6 & Finishing & & $\begin{array}{l}\text { - The last step is to do the finishing stage by coating the } \\
\text { outer layer of wood. In this proces it is useful to give } \\
\text { the appearance of the wood color more clearly to show } \\
\text { the wood fibers itself. }\end{array}$ \\
\hline
\end{tabular}

Source: (Kalingga Gallery, edited by the author, 2021)

\section{Conclusion}

Based on the analysis results, it can be concluded that the use of the material in the house of the Sitinggil makes use of material the used wood as the structure and the construction is. It is a sustainable house if viewed from the use of material. The wood material used is a type of wood for level II Rasamala for the necessity constructions of weight, unprotected and exposed to moist soil. Used wood dimensions smaller than the new wood dimension; therefore, a column or wood beam was incorporated using the clamped cleat to get larger dimensions. Several points the results of the analysis from form a roof, type foundation, size, and processing used wood as follows:

1. the roof is used on the house and terrace, namely the gable half, while the roof on the cafe uses a gable roof that experienced the development. The use of gable chosen as few use the structure connection and is practical. 
2. Columns and beams of used wood on a house, terrace, and cafe having dimensions $5 / 7,6 / 12$, and 10/10, its usage adapted to a function the structure and the mass of the building. The connection used the splice, squared, and half lap connection rigid enough. 3. Used in the building foundation Sitinggil overall use of umpak foundation with types and cube dimples. The house and cafe use lesung foundation with dimensions more excellent because burdened two floors while in terrace use umpak foundation type cubes dimensions with smaller because only a roof terrace loaded of small.

4. After going through various processing stages, wood that is readily used of wood that has in finishing with the outer layer of wood has been coated to show itself wood fiber. Of all the stages in processing, used wood aim in order more robust, durable, and avoid attacks termites.

Besides being used as a structural and construction of house building, used wood can be further researched is to other uses, such as making furniture and the craft.

The benefits obtained from using wood as a structural and construction material for the Sitinggil House are that it does not reduce the strength of the building structure because the used wood is joined and clamped to get dimensions according to the wood strength standards. The scope of this research includes the dimensions and connections at the structure column, beam, and roof to get measurements to adjust to the wood strength standard. Recommendations for further research can be studied about testing strong press used wood.

\section{References}

[1] Permen LHK number p.83/menlhk/setjen/kum.1/10/2016 About Social Forestry

[2] Priambodo, Taufik, Ir, 2008. The Middle House Structure and Construction. Jakarta: Griya Kreasi
[3] Supribadi, I.K., Drs, 1993. The Science of The Building. Bandung: Armico

[4] SK SNI T-15-1991-03 The Procedure Calculation Structure Concrete to The Building

[5] Frick Heinz, Ir; 1982; The science of wooden building construction; Yogyakarta: Kanisius

[6] SK SNI 7973-2013-04 Specification a design for wooden construction

[7] Nuryanto; 2006; Of Continuity and a Change in Village Pattern and Residential of Kasepuhan Ciptarasa to Ciptagelar on Kab.Sukabumi-Jawa Barat; Reports the Masters in Architecture, SAPPK-ITB. Unpublished

[8] RSNI The revision of the wooden construction regulations $\mathrm{NI}-5-2002$

[9] Ervianto, Wulfram I, 2012. Save the earth through green construction. Yogyakarta: Andi Offset.

[10] Kalingga Gallery, Used Wood, (edited) 2021

[11] SNI 03-6851-2002 A method of testing structural wood paneling pliant

[12] Studio Akanoma, Rumah Sitinggil Dago, (edited) 2021 
(This page is intentionally left blank) 